\title{
What News Drive Variation in Swiss and US Bond and Stock Excess Returns?
}

\author{
Thomas NitschKa ${ }^{\mathrm{a}}$
}

JEL-Classification: E44, G12.

Keywords: bond return, news components, stock return, variance decomposition.

\section{Introduction}

Variation in asset returns reflects revisions in expectations about cash-flows, real interest rates or risk premia or an arbitrary combination of the three. This is the fundamental insight from the log-linear approximation of the standard present value model that links stock prices, stock returns and dividends proposed by Campbell and Shiller (1988). Hence, seemingly similar asset return fluctuations could reflect very different causes. This is a particularly important topic for all researchers, including monetary policymakers, who monitor asset returns as indicators of financial market participants' expectations. For instance, Campbell, Giglio and Polk (2013) show that the 2000-2002 US stock market bust was largely driven by considerably higher than expected future risk premia while the 2007-2009 US stock market downturn reflected to a good deal worse than expected cash-flow news. High expected risk premia lower the current asset value but also signal better future investment opportunities. By contrast, bad news about the future stream of cash-flows persistently lower the value of an asset and reflect bad news of future (macroeconomic) fundamentals.

a Swiss National Bank, P.O. Box, Boersenstrasse 15, CH 8022 Zuerich, Switzerland, thomas. nitschka@snb.ch. I would like to thank an anonymous referee of this journal, Katrin Assenmacher, Alain Gabler, Pierre Monnin, an anonymous referee of the Swiss National Bank Working Paper Series as well as participants in the SNB Brown Bag seminar for helpful comments and suggestions. An earlier version of this paper circulated under the title "The Good? The Bad? The Ugly? Which news drive (co)variation in Swiss and US bond and stock excess returns?" published as SNB working paper 2014-1. The views expressed in this paper are those of the author and not necessarily representative of the views of the Swiss National Bank. Any errors and omissions are my own. 
Moreover, Kocherlakota (2013) suggests that the past years of very low, even negative, real interest rates might have led to a situation in which firms and households pay more attention to news about macroeconomic risks, i.e. the fundamentals that underlie the value of assets, than before this period. As a consequence, such news could account for more of the variability of asset returns than in times of "normal" real interest rate levels. In this respect, Switzerland is a particularly interesting case because it does not only experience a long period of low real interest rates since 2009 (see e.g. Swiss National Bank, 2013). It was also directly affected by the banking crisis in 2008/2009 and is still affected by the on-going euro area crisis since Swiss assets (including the exchange rate) are typically perceived as "safe haven" assets (Kugler and Weder, 2005; Grisse and Nitschka, 2013; Hoffmann and Suter, 2010; Ranaldo and Söderlind, 2010) by global investors. ${ }^{1}$

To provide an empirical account of the relative importance of news of future fundamentals or risk premia, I use the vector autoregression (VAR) framework of Campbell and Ammer (1993) to decompose returns on the Swiss stock market and 10-year government bond returns in excess of a short-term interest rate into news components that reflect future cash-flows, real interest rates and expected risk premia. ${ }^{2}$ For comparison, I perform similar decompositions for the US.

Variance decompositions show that cash-flow news (dividend news in the case of stocks, inflation news in the case of bonds) are the main driving force of monthly, unexpected stock and bond excess returns in Switzerland in the time period from January 1975 to July 2013. By contrast, variation in excess returns on the US stock and bond markets reflects a considerably higher impact of news of future risk premia on unexpected asset return movements over the same sample period.

Furthermore, variance decompositions based on estimates from threshold VARs - in which the threshold is defined relative to ex-post real interest rate levels to assess the general validity of the arguments of KOCHERLAKOTA (2013) - show that cash-flow news is clearly the main driver of stock market return dynamics in periods of low real interest rates in the US. This evidence supports the

1 Habib and StracCa (2012) provide an assessment of country characteristics that determine "safe havens". According to their criteria, Switzerland is a prime example of a "safe haven" country.

2 Typically, the two markets are studied in isolation (CAMPBELL, 1991; Viceira, 2008) and if both markets are analyzed jointly, the analysis is usually confined to the US and UK (SHILLER and Beltratti, 1992; Campbell and Ammer, 1993). A notable exception in this respect is EngSted and TAnggaArd (2001) who jointly study the Danish stock and bond market. 
intuition of Kocherlakota (2013). However, this finding does not pertain to Switzerland or the US bond market. In these cases the distinction between periods of low and high real interest rate levels does not reveal any differences in the dynamics of asset returns.

The remainder of this paper is organized as follows. Section 2 briefly highlights the basic stock and bond return relationships used to decompose stock and bond returns into three different news components: news about cash-flows, real interest rates and risk premia. Section 3 describes the econometric framework and the data. Section 4 provides the empirical results. Finally, section 5 concludes.

\section{The Basic Stock and Bond Return Relationship}

The empirical framework of this paper is based on the dynamic accounting identity that links asset returns to expected cash-flows and discount rates derived in Campbell and Shiller (1988) and used by Campbell (1991) to break unexpected returns on stocks into components reflecting news about cash-flows and discount rates (real interest rate plus risk premium). Shiller and Beltratti (1992) and Campbell and Ammer (1993) show that this accounting framework straightforwardly applies to bond returns too. The next two subsections briefly describe these relations.

\subsection{The Basic Stock Return Relationship}

The starting point of CAMPBell and Shiller (1988) is the two-period present value model that links current stock prices to dividends and returns, i.e.

$$
1+r_{t+1}=\frac{P_{t+1}+D_{t+1}}{P_{t}}
$$

with $r$, the net return on the stock, $P$, the stock price excluding dividends, and $D$, denoting dividends.

Equation (1) implies that if stock prices and dividends are non-stationary, then returns should be stationary. However, stock returns vary and they vary by a lot at business cycle frequencies as risk aversion varies over the business cycle (e.g. Campbell and Cochrane, 1999). To allow for such time-varying returns, Campbell and Shiller (1988) propose a log-linear approximation of equation (1) around the mean dividend-price ratio. This approximation yields 


$$
r_{t+1} \approx k+\rho p_{t+1}+(1-\rho) d_{t+1}-p_{t}
$$

where lower-case letters denote logarithms of the variables. The letter $k$ summarizes all constant terms following from the Taylor expansion and $\rho=1 /(1+\exp (d-p))$ is a weight that also follows from the log-linearization. This weight depends on the long-run mean of the log dividend-price ratio, $d-p$, around which equation (1) is linearized. This weight is slightly lower than unity.

To arrive at a representation of unexpected stock return movements we have to rearrange equation (2) for the stock price, $p_{t} \approx k+\rho p_{t+1}+(1-\rho) d_{t+1}-r_{t+1}$ and then expand this equation to the infinite horizon imposing the condition that discounted stock prices cannot grow forever at a rate higher than $\rho, \lim _{j \rightarrow \infty} \rho^{j} p_{t+j}=0$, and take expectations on both sides of the equation such that

$$
p_{t}=\frac{k}{1-\rho}+E_{t}\left[\sum_{j=0}^{\infty} \rho^{j}\left((1-\rho) d_{t+1+j}-r_{t+1+j}\right)\right]
$$

with $E_{t}$ the expectation operator conditional on information at time $t$. Substituting equation (3) into equation (2), CAMPBELL (1991) shows that unexpected changes of stock returns either reflect news (revisions in expectations) of dividend growth or future discount rates, i.e.

$$
r_{t+1}-E_{t} r_{t+1}=\left(E_{t+1}-E_{t}\right) \sum_{j=0}^{\infty} \rho^{j} \Delta d_{t+1+j}-\left(E_{t+1}-E_{t}\right) \sum_{j=0}^{\infty} \rho^{j} r_{t+1+j}
$$

Campbell and Ammer (1993) suggest to study excess returns, i.e. stock returns in excess of a short-term debt rate. In addition, they assume that the discount rate, $r$, is the sum of short-term real interest rates, $r r$, and a risk premium term, $r x$, i.e. $r=r r+r x$. Then the discount rate term in equation (4) can be reformulated such that unexpected stock excess returns obey

$$
r x_{t+1}-E_{t} r x_{t+1}=\left(E_{t+1}-E_{t}\right)\left\{\sum_{j=0}^{\infty} \rho^{j} \Delta d_{t+1+j}-\sum_{j=0}^{\infty} \rho^{j} r r_{t+1+j}-\sum_{j=1}^{\infty} \rho^{j} r x_{t+1+j}\right\}
$$

For notational convenience, I follow CAMPBell (1991) and rewrite equation (5) as

$$
N R_{t+1}=N C F_{t+1}-N R R_{t+1}-N R X_{t+1}
$$


with

$N R_{t+1} \equiv r x_{t+1}-E_{t} r x_{t+1} \quad$ being the unexpected stock market excess return,

$N C F_{t+1} \equiv\left(E_{t+1}-E_{t}\right) \sum_{j=0}^{\infty} \rho^{j} \Delta d_{t+1+j} \quad$ the news of future cash-flows (dividends),

$N R R_{t+1} \equiv\left(E_{t+1}-E_{t}\right) \sum_{j=0}^{\infty} \rho^{j} r r_{t+1+j} \quad$ the news of the real interest rate,

and finally

$$
\begin{aligned}
N R X_{t+1} \equiv\left(E_{t+1}-E_{t}\right) \sum_{j=1}^{\infty} \rho^{j} r x_{t+1+j} & \begin{array}{l}
\text { the news of future excess returns which } \\
\text { can be interpreted as proxy of expected } \\
\text { risk premia. }
\end{array}
\end{aligned}
$$

Following from this accounting identity a positive surprise movement in the excess stock market return is associated with positive dividend news, lower than expected real interest rates or lower than expected future excess returns or an arbitrary combination.

\subsection{The Basic Bond Return Relationship}

A similar decomposition as the one for stock excess returns applies to bond returns. Define the real, log bond return in excess of the short-term rate as

$$
b r x_{t+1}^{N} \equiv b_{t+1}^{N}-\pi_{t+1}-r r_{t+1}
$$

in which $b_{t+1}^{N} \equiv p_{t+1}^{N-1}-p_{t}^{N}$ is the log nominal one-period holding return on a $N$-period zero-coupon bond with nominal price, $p$. Inflation is denoted by $\pi$ and $r r$ represents the short-term real rate. In their Appendix A, CAMpBell and Ammer (1993) show that the unexpected bond excess return for a bond with maturity $N$ held from $t$ to $t+1$ (at which it becomes a $N-1$ period bond) obeys

$$
b r x_{t+1}^{N}-E_{t} b r x_{t+1}^{N}=\left(E_{t+1}-E_{t}\right)\left\{-\sum_{i=1}^{N-1} \pi_{t+1+i}-\sum_{i=1}^{N-1} r r_{t+1+i}-\sum_{i=1}^{N-1} b r x_{t+1+i}^{N-1}\right\}
$$

or in more compact notation 


$$
N B R_{t+1}=-N B C F_{t+1}-N B R R_{t+1}-N B R X_{t+1}
$$

with

$$
\begin{array}{ll}
N B R_{t+1} \equiv b r x_{t+1}^{N}-E_{t} b r x_{t+1}^{N} & \begin{array}{l}
\text { being the unexpected excess return on the } \\
n \text {-period, zero-coupon bond, }
\end{array} \\
N B C F_{t+1} \equiv\left(E_{t+1}-E_{t}\right) \sum_{i=1}^{N-1} \pi_{t+1+i} & \begin{array}{l}
\text { the cash-flow, i.e. inflation, news compo- } \\
\text { nent, }
\end{array} \\
N B R R_{t+1} \equiv\left(E_{t+1}-E_{t}\right) \sum_{i=1}^{N-1} r r_{t+1+i} & \begin{array}{l}
\text { the real interest rate news over the lifetime } \\
\text { of the bond, }
\end{array}
\end{array}
$$

and

$N B R X_{t+1} \equiv\left(E_{t+1}-E_{t}\right) \sum_{i=1}^{N-1} b r x_{t+1+i}^{N-1} \quad$ the news about bond excess returns.

A positive, unexpected bond excess return hence reflects an unexpected decline in inflation over the maturity of the bond, lower than expected real interest rates or lower than expected bond excess returns. Inflation corresponds to cash-flows because the bond price at the maturity date is fixed in nominal terms. Even when expected real interest rates or excess returns stay constant, the expected real payoff of the bond could vary because of changes in inflation over the lifetime of the bond.

\subsection{Variance Decompositions with Correlated News Components}

To assess the relative importance of the different news components of stock and bond excess returns, this paper follows Campbell and Ammer (1993) in decomposing the variance of the unexpected stock and bond excess returns. The different news components are correlated with each other such that the variance decomposition of e.g. the stock excess return obeys

$$
\begin{aligned}
\operatorname{var}(N R)= & \operatorname{var}(N C F)+\operatorname{var}(N R R)+\operatorname{var}(N R X) \\
& -2 \operatorname{Cov}(N C F, N R R)-2 \operatorname{Cov}(N C F, N R X) \\
& +2 \operatorname{Cov}(N R R, N R X)
\end{aligned}
$$

This decomposition takes explicitly correlations between the different news components into account. This is economically interesting information. For example, 
the Swiss assets studied in this paper are typically considered to be "safe haven" assets. They are considered as a hedge against the materialization of global disaster risks (Kugler and Weder, 2005; Grisse and Nitschka, 2013; Hoffmann and Suter, 2010; Ranaldo and Söderlind, 2010). Does this imply that risk premium news and news about fundamentals move in the same direction reinforcing each other? Or are these news rather uncorrelated meaning that fundamentals and risk premium shocks are clearly distinct?

Again following Campbell and Ammer (1993), I report the statistics of the right-hand side of equation (10) in the empirical part of this paper. These statistics are normalized by the variance of the unexpected asset return, $\operatorname{var}(N R)$ or $\operatorname{var}(N B R)$, such that the sum of the variance and covariance terms of the different news components add up to one.

\section{Empirical Framework and Data}

Revisions in expectations of excess returns and their components are not directly observable such that CAMPBell and Ammer (1993) propose a VAR model to identify the different news components.

\subsection{Obtaining News Components from a VAR}

The VAR for each country is based on a state vector which contains the stock excess return as its first element. Then follows the short-term, ex post measured, real interest rate, the change in the short-term nominal interest rate and the spread between a long-term government bond yield and the short-term interest rate. These four elements are necessary to back out the different stock and bond excess return news components.

To address the criticism of VAR-based return decompositions of CHEN and Zhao (2009) and following the recommendations of Engsted, Pedersen and TANGgaARD (2012), the state vector includes as its fifth element the dividendprice ratio. Engsted, Pedersen and Tanggaard (2012) show that including the dividend-price ratio as state variable alleviates concerns about the choice of stock market news component to be obtained as residual from the VAR. This is the case as long as the state variables have the potential to not only signal future returns but also future cash-flows. The dividend-price ratio has to signal dividends or returns by construction.

Campbell and Shiller (1988) show how to reformulate a p-order VAR into a first-order VAR representation. For notational convenience, I hence present 
the ways to back out the different news components from the example of a firstorder VAR:

$$
z_{t+1}=\Gamma z_{t}+u_{t+1}
$$

in which $\Gamma$ is the matrix of VAR coefficients and $u$ denotes the error terms. Further define the $6 \times 1$ vectors el to e 4 to pick out different elements of the state vector. The first element in el is one and all other elements are zero, the second element in e2 is one and all other elements zero and analogously for the other vectors $\mathrm{e} 3$ and $\mathrm{e} 4$.

The news of the stock excess return can be directly obtained from equation (11) as $N R_{t+1}=\mathrm{e}^{\prime} u_{t+\mathrm{t}}$ because the stock excess return is the first element of the state vector. News of the bond excess return can be derived from news of the short-term interest rate and news of the yield spread, i.e. $N B R_{t+1}=-(n-1)\left(\mathrm{e} 3^{\prime}+\mathrm{e} 4^{\prime}\right) u_{t+1}$, thus exploiting that excess return news can equivalently be written as news of future bond yields. This latter news can again be written as the sum of news of changes in the short-rate ${ }^{3}$ and the term yield spread (CAmpbell and Ammer, 1993).

The other news components are derived from (11) by using the VAR estimates to compute revisions in (long-horizon) expectations as

$$
\left(E_{t+1}-E_{t}\right) z_{t+1+j}=\Gamma^{j} u_{t+1}
$$

In both stock and bond excess return decompositions two of the three different news components can be directly computed from the VAR estimates such that the third component has to be obtained as a residual.

\subsubsection{Stock Market Excess Return News}

The three news components of the stock market excess return are obtained in the following way. News of future expected stock market excess returns can be directly derived from the VAR estimates as

$$
N R X_{t+1}=\mathrm{e}^{\prime} \sum_{j=1}^{\infty} \rho^{j} \Gamma^{j} u_{t+1}=\mathrm{e}^{\prime} \rho \Gamma(I-\rho \Gamma)^{-1} u_{t+1}
$$

3 This is due to the fact that the lagged short rate is known at time t such that innovations in the change of the short rate basically reflect innovations in the level of the short rate. 
and news of future real interest rates obey

$$
N R R_{t+1}=\mathrm{e} 2^{\prime} \sum_{j=0}^{\infty} \rho^{j} \Gamma^{j} u_{t+1}=\mathrm{e} 2^{\prime}(I-\rho \Gamma)^{-1} u_{t+1}
$$

The news of future cash-flows of the stock market excess return is then obtained as residual, i.e.

$$
N C F_{t+1}=N R_{t+1}+N R X_{t+1}+N R R_{t+1}
$$

As emphasized in Campbell (1991), modelling the cash-flow news as residual in the context of stock returns helps to avoid potential problems with the measuring of dividends which are highly seasonal.

\subsubsection{Bond Market Excess Return News}

From the VAR estimates we can directly derive the news about real interest rates over the lifetime of the bond as

$$
N B R R_{t+1}=\mathrm{e} 2^{\prime} \sum_{i=1}^{n-1} \Gamma^{j} u_{t+1}=\mathrm{e} 2^{\prime}(I-\Gamma)^{-1}\left(\Gamma-\Gamma^{n}\right) u_{t+1}
$$

and cash-flow (inflation news) as

$$
N B C F_{t+1}=-N B R R+\mathrm{e}^{\prime}\left\{(I-\Gamma)^{-1}\left[(n-1) I+(I-\Gamma)^{-1}\left(\Gamma^{n}-\Gamma\right)\right]\right\} u_{t+1}
$$

such that news of future bond excess returns is obtained as the residual.

$$
N B R X_{t+1}=-N B R_{t+1}-N B R R_{t+1}-N B C F_{t+1}
$$

Since directly estimating the excess return news would require to take the shrinking maturity of the bond into account, we have to obtain that news component as the residual (CAmpbell and Ammer, 1993; Engsted, Pedersen and TANGGAARD, 2012). 


\subsection{Threshold VAR}

Kocherlakota (2013) suggests that the recent period of exceptionally low, i.e. negative, real interest rate levels might have led to a situation in which market participants put more weight on long-term economic news (inflation news in the case of bonds, dividend news in the case of stocks) than during times of "normal" real interest rate levels.

In order to assess this intuition I use a threshold VAR framework to obtain VAR estimates and back out the corresponding asset return news components for periods of particularly low and "normal" real interest rate levels. ${ }^{4}$ The threshold is defined relative to ex post measured, monthly real interest rate levels in Switzerland and the US respectively.

In the subsequence, I report results (VAR estimates, variance decompositions) based on the distinction between negative and positive real interest rate levels. This is a natural threshold given that Kocherlakota (2013) emphasizes the negative real interest rate levels in the US during the recent years. Note that I define the threshold in terms of the respective country's real interest rate. The threshold VARs hence differ between the two countries.

The threshold VAR specification used in this paper for either Switzerland or the US can then be expressed as

$$
z_{t+1}= \begin{cases}\Gamma^{h} z_{t}+u_{t+1}^{h} & \text { if } r r_{t+1}>0 \\ \Gamma^{l} z_{t}+u_{t+1}^{l} & \text { if } r r_{t+1}<0\end{cases}
$$

in which $r r$ represents the monthly, ex post measured real interest rate of Switzerland or the US. I use the estimates from the threshold VARs in equation (19) to back out the different news components of the asset returns under study for the high and low real interest rate periods and thus to perform the variance decompositions. These variance decompositions should give an indication if the intuition of Kocherlakota (2013) applies to low (negative) real interest rate periods in general and not only to the recent period of exceptionally low real interest rates. For example, Switzerland does not only experience a period of negative real interest rates since 2009 but witnessed negative real interest rates from 2002 to 2006 and in the late 1970s as well. Hence, in terms of low real interest rates, the recent period is not unique.

4 I thank an anonymous referee of this journal for suggesting this course of analysis.

5 A working paper version of this paper focused only on the last five years of low real interest rates. 


\subsection{Data and Sample Period}

I follow Campbell and Ammer (1993) and include the following variables in the state vector: the excess return on the stock market $(r x)$, the short-term, ex post real interest rate $(r r)$, changes in the nominal short-term rate $(\Delta i)$, the spread between yields on long-term bonds and a short-rate (yield spread, ys), and the $\log$ dividend-price ratio $(d p)$. The frequency of the data is monthly. The baseline sample period runs from January 1975 to July 2013.

The source of constant maturity 10 -year government bond yields for Switzerland is the Swiss National Bank (SNB). In addition, I use the one-month CHF Libor obtained from Datastream as proxy of the Swiss nominal short-term rate at the monthly frequency. Following Campbell and Ammer (1993), the yield spread is calculated as difference between the yield on the 10-year zero-coupon government bond and the two-month short rate ${ }^{6}$, here the two-month CHF Libor, in percentage points p.a. For the US I use the constant maturity 10 -year treasury bill rate and three-month Treasury bill rate to construct the term yield spread. These series are from the website of the Federal Reserve Board. I use the one-month Treasury bill rate to calculate changes in short-rates, the ex post real interest rate and monthly stock excess returns. This series is obtained from Kenneth French's data library.

To calculate monthly, ex post real interest rates, I subtract monthly changes (in $\%$ per month) of the seasonally adjusted Swiss consumer price index (CPI) from the nominal short-term interest rate (in \% per month). The CPI index excludes oil related products and adjusts for special seasonal patterns in clothing and shoes in Switzerland. The source of the CPI data is the Swiss Federal Statistical Office and the SNB. For the US, I use total personal consumption expenditure (PCE) index data and PCE excluding food and energy prices from the NIPA table 2.3.4 available on the website of the Bureau of Economic Analysis.

To calculate stock returns and dividend-price ratios I use Swiss and US price and total return (assuming that dividend payments are reinvested) stock market index data, denominated in the respective local currency, from MSCI. The MSCI indices have the advantage that they cover a large share of the market capitalization and are constructed using the same methodology. They are thus easily comparable across countries. Following the usual convention in the literature, the monthly log dividend-price ratio is obtained as log of the sum of monthly

6 Usually, the yield spread is measured between the 10-year yield and a one-month yield/rate. This is not possible in the current context as shocks to the one-month rate are explicitly taken into account in the estimation of the VAR. 
dividends over the past year minus the log of this month's stock price index. Monthly dividends are obtained as difference between the return on the total return index (including dividend payments) in $t+1$ minus the return on the price index (excluding dividend payments) in $t+1$ times the stock price index in $t$. Annual dividends are the sum of the monthly dividends. Annualising the dividends helps to avoid seasonal patterns in dividends. Excess returns are expressed in percent per month.

\section{Empirical Results}

This section presents all of the empirical results. It starts with the estimates from the VAR for the three sample periods under study. Then I report the return decompositions and assess the correlation of the different stock and bond return news components. Finally, this section summarizes some robustness checks.

\subsection{VAR Estimates}

This section presents the estimates of a first-order standard VAR as in equation (11) as well as the estimates from the threshold VARs as introduced in equation (19). The lag of one month is suggested by Akaike and Schwartz information criteria for Swiss and US data.

Panel A of table 1 gives the VAR estimates for Switzerland over the baseline sample period from January 1975 to July 2013. The first line of panel A shows that the stock market excess return is only predicted by its own lag. Judged by the Newey-West corrected t-statistics of the VAR estimates, the other one-month lagged variables do not significantly signal future excess returns. The $\mathrm{R}^{2}$ statistic adjusted for the number of regressors is about $2 \%$. This result is common when assessing one-month ahead time variation in stock market returns. Most empirical studies of stock return predictability find that the forecasting power for stock returns peaks at the business cycle frequency (e.g. Cochrane, 2011). The other lines of panel $A$ of table 1 give the results for the other variables.

Panels B and C of table 1 present the VAR estimates for the high (Panel B) and low (Panel C) real interest rate periods. The results shown in panel B of table 1 depend on 326 months in which the Swiss real interest rate was positive. The results in panel C of table 1 are obtained from the 137 months in which the monthly real interest rate was negative.

The stock return forecasting equation reveals some differences between the two samples. The term yield spread significantly predicts the stock market excess 
return when real interest rates are positive but not when real interest rates are negative. The opposite is true for the dividend-price ratio. Overall predictability, however, is roughly similar across the two samples. The other VAR estimates largely corroborate the baseline, standard VAR estimates.

The US VAR estimates, reported in table 2, reveal even less predictability of the stock market excess returns during the sample period under study both in the standard and the threshold VAR. The VAR estimates over the baseline sample period and from the threshold VAR are broadly similar. For the US, the high real interest rate period covers 340 months while the negative real interest period comprises 123 months.

The two countries' VAR results show that the link between one-month ahead stock market excess returns and predictors such as the term spread is considerably weaker than reported in e.g. Campbell, Giglio and Polk (2013) for the US. The main reason for this difference is the shorter sample period. While Campbell, Giglio and Polk (2013) estimate their VAR from 1929 to 2010, this paper's sample period starts in 1975. The insignificant VAR coefficients for the term spread are in line with the subsample estimates in GaLSBAND and Nitschka (2013). Moreover, instead of the dividend-price ratio, the priceearnings ratio is typically used as state variable in studies focused on the US (Campbell and Ammer, 1993; Campbell, Giglio and Polk, 2013) which delivers significant estimates in stock return forecast regressions. Since the price-(long-term) earnings ratio for the Swiss MSCI index is not available, I use dividend-price ratios to ensure that cross-country differences in the variance decompositions are not due to the use of different state variables to back out the news components.

Before turning to the variance decompositions, figure 1 depicts the estimated unexpected movements of stock and 10-year government bond excess returns in Switzerland (solid lines) and the US (dotted lines). The upper panel of the figure presents the unexpected stock excess return movements while the lower panel gives the unexpected bond excess return movements over time. These series are smoothed as in Campbell, Giglio and Polk (2013).

The upper panel of figure 1 gives the smoothed unexpected stock market excess return series over the baseline period from February 1975 to July 2013. We observe several pronounced swings that are broadly similar for both Swiss and US data. The 1987 crash is visible as unexpected negative return variation. In the early and mid-1990s we see periods of mostly positive unexpected excess returns. By contrast, the 2000s are mostly characterized by negative news reflecting the downturn after the NASDAQ boom and more recently around the collapse of Lehman Brothers. 
Table 1: VAR Estimates (Switzerland)

\begin{tabular}{|c|c|c|c|c|c|c|}
\hline & $r x_{t-1}$ & $r r_{t-1}$ & $\Delta i_{t-1}$ & $y s_{t-1}$ & $d p_{t-1}$ & $R^{2}$ \\
\hline \multicolumn{7}{|c|}{ Panel A: Standard VAR estimates; baseline sample period January 1975 to July 2013} \\
\hline$r x_{t}$ & $0.16^{*}(3.46)$ & $0.26 \quad(0.20)$ & $0.01(-0.03)$ & $0.19 \quad(1.34)$ & $0.66 \quad(1.04)$ & 0.02 \\
\hline$r r_{t}$ & $0.00(-0.80)$ & $0.04 \quad(0.96)$ & $0.01(-0.45)$ & $0.05^{*}(-8.69)$ & $0.11^{*}(-4.61)$ & 0.19 \\
\hline$\Delta i_{t}$ & $0.01 \quad(1.62)$ & $0.27^{*}(-1.97)$ & $0.06 \quad(1.30)$ & $0.03 \quad(1.74)$ & $0.05 \quad(0.71)$ & 0.03 \\
\hline$y s_{t}$ & $0.01 \quad(-1.33)$ & $0.49^{*} \quad(3.66)$ & $0.05 \quad(1.16)$ & $0.98^{*}(62.77)$ & $0.03 \quad(0.48)$ & 0.91 \\
\hline$d p_{t}$ & $0.00^{*}(-2.70)$ & $(0.09)$ & $(0.29)$ & $0.00 \quad(-1.03)$ & $0.97^{*}(96.73)$ & 0.96 \\
\hline \multicolumn{7}{|c|}{ Panel B: Threshold VAR estimates; threshold: $r r_{t}>0$} \\
\hline$r x_{t}$ & $0.04 \quad(0.68)$ & $(0.93)$ & $0.23 \quad(0.38)$ & $0.45^{*} \quad(2.35)$ & $0.05 \quad(-0.07)$ & 0.01 \\
\hline$r r_{t}$ & $0.00 \quad(0.21)$ & $0.19^{*} \quad(3.57)$ & $0.03 \quad(-1.73)$ & $0.04^{*}(-7.53)$ & $0.00^{*}(-0.12)$ & 0.28 \\
\hline$\Delta i_{t}$ & $0.01^{*}(2.77)$ & $0.07 \quad(-0.35)$ & $0.06 \quad(1.04)$ & $0.00 \quad(0.17)$ & $0.04 \quad(-0.55)$ & 0.02 \\
\hline$y s_{t}$ & $0.01 \quad(-1.94)$ & $0.30 \quad(1.23)$ & $0.11 \quad(1.60)$ & $0.96^{*}(44.46)$ & $0.04 \quad(-0.49)$ & 0.89 \\
\hline$d p_{t}$ & $0.00 \quad(-1.68)$ & $0.00 \quad(-0.08)$ & $0.00 \quad(-0.24)$ & $0.01 \quad(-1.55)$ & $0.95^{*}(65.26)$ & 0.94 \\
\hline \multicolumn{7}{|c|}{ Panel C: Threshold VAR estimates; threshold: $r r_{t}<0$} \\
\hline$r x_{t}$ & $0.09 \quad(-1.07)$ & (1.68) & $0.16(-0.26)$ & $0.02 \quad(0.10)$ & $3.59^{*} \quad(2.62)$ & 0.02 \\
\hline$r r_{t}$ & $0.00 \quad(0.38)$ & 0.12 & $0.01 \quad(-0.60)$ & $0.02 *$ & $0.08^{*}(-2.43)$ & 0.12 \\
\hline$\Delta i_{t}$ & $0.01 \quad(-1.01)$ & $0.98 \quad(-1.89)$ & $(1.95)$ & $0.09^{*}(2.50)$ & $0.17^{*} \quad(0.92)$ & 0.07 \\
\hline$y s_{t}$ & $0.01 \quad(-0.43)$ & $1.84^{*} \quad(2.74)$ & $0.07 \quad(0.65)$ & $0.83^{*}(18.44)$ & $0.06 \quad(0.23)$ & 0.74 \\
\hline$d p_{t}$ & $0.00 \quad(-0.71)$ & 0.00 & $(0.24)$ & $0.01 \quad(-1.00)$ & $0.91^{*}(24.04)$ & 0.83 \\
\hline
\end{tabular}

Notes: This table presents estimates from a vector autoregression (VAR) with lag length of one month of the following variables: the excess return on the Swiss stock market $(r x)$, the short-term real interest rate $(r r)$, changes in the nominal short-term rate $(\Delta i)$, the spread between yields on long-term bonds and a short-rate (yield spread, $y s)$ and the log dividend-price ratio $(d p)$ Panel A gives the estimates from a standard VAR using data over the full sample period from January 1975 to July 2013 Panels B and C present estimates from a threshold VAR where the threshold variable is the level of the ex post, monthly real interest rate. Panel B shows the threshold VAR estimates for states of the world when the real interest rate was positive. Panel $\mathrm{C}$ gives the corresponding results for states of the world when the real interest rate was negative. Newey-West corrected t-statistics appear beside the estimates in parenthesis. The measure of fit, $R^{2}$, is corrected for the number of regressors. 
Table 2: VAR Estimates (US)

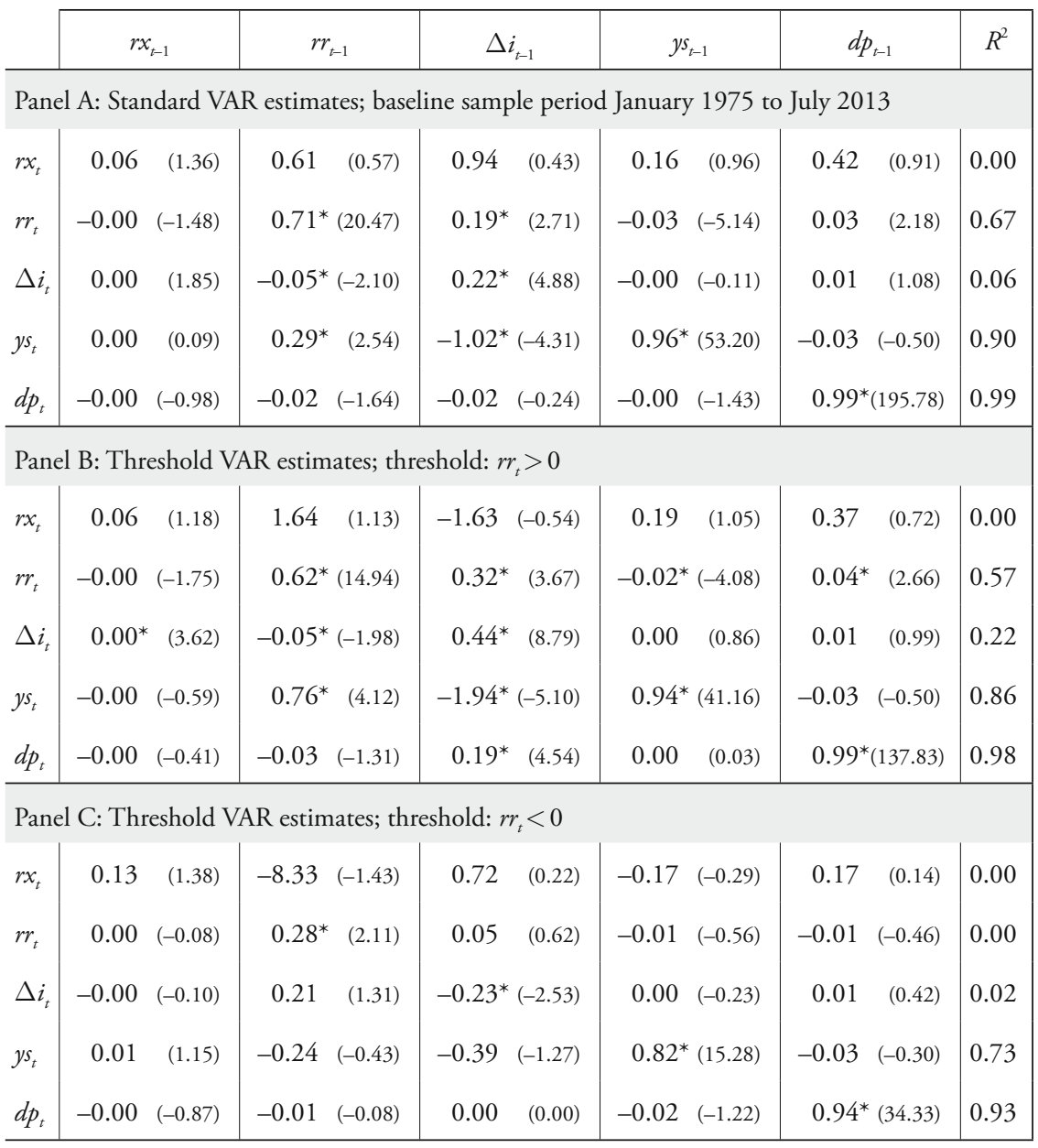

Notes: This table presents estimates from a vector autoregression (VAR) with lag length of one month of the following variables: the excess return on the US stock market $(r x)$, the short-term real interest rate $(r r)$, changes in the nominal short-term rate $(\Delta i)$, the spread between yields on long-term bonds and a short-rate (yield spread, $y s)$ and the log dividend-price ratio $(d p)$ Panel A gives the estimates from a standard VAR using data over the full sample period from January 1975 to July 2013 Panels B and C present estimates from a threshold VAR where the threshold variable is the level of the ex post, monthly real interest rate. Panel B shows the threshold VAR estimates for states of the world when the real interest rate was positive. Panel C gives the corresponding results for states of the world when the real interest rate was negative. Newey-West corrected t-statistics appear beside the estimates in parenthesis. The measure of fit, $R^{2}$, is corrected for the number of regressors. 


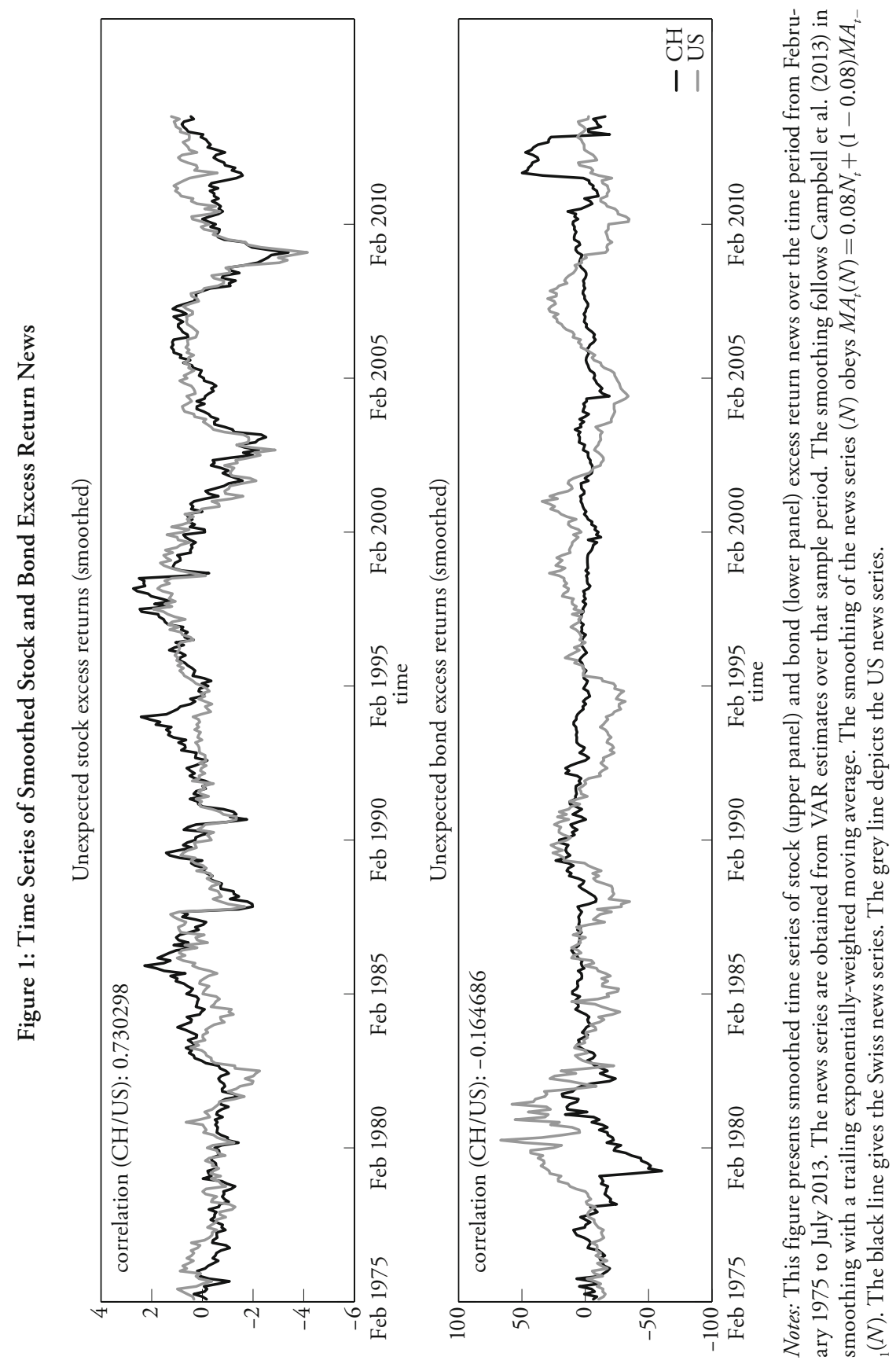


The lower panel of figure 1 presents the smoothed 10-year bond excess return news series. The correlation between the Swiss and the US series is considerably lower, a correlation coefficient of -0.16 , than for the stock news series, a correlation coefficient of more than 0.7. This lower, even slightly negative, correlation between US and Swiss bond return news reflect that we observe more episodes of swings from negative to positive unexpected movements in bond excess returns especially in the 1980s and 1990s and clearly during the Lehman Brothers collapse in the US than in Switzerland.

Compared with the stock excess return news series, news of Swiss bond excess returns typically do not exhibit so many pronounced swings. There are two episodes that stand out. The first one occurred at the beginning of the sample period around the second oil price shock in the late 1970s and coincides with the introduction of a minimum rate for the Swiss franc against the Deutschmark. The second one occurred around the intensification of the euro area crisis in 2010/2011 which ultimately prompted the SNB to introduce a minimum exchange rate against the euro to fight deflationary pressures. In the course of this crisis, Swiss assets have been perceived as valuable insurance against euro area risks. At the same time, Swiss inflation rates turned negative and were heavily influenced by extreme exchange rate movements during these periods because Switzerland is a small, open economy. It could be the case that the bond return variation generally reflects the impact of exchange rate movements on Swiss long-term inflation expectations which hence could lead to unexpected variation in bond excess returns. ${ }^{7}$ A priori, it is hence not clear what effects (Swiss bonds' hedging value against risk or Swiss inflation news potentially triggered by exchange rate fluctuations) led to revisions in expectations of future bond excess returns.

\subsection{Variance Decomposition with Correlated Components: Stock Excess Return}

The variance decompositions show that cash-flow news clearly dominate the variance of unexpected stock return movements in Switzerland irrespective of the distinction between high and low real interest rates. By contrast, news of future risk premia have far more importance for variation in US stock market returns with the exception of the negative real interest rate periods. This latter finding supports the intuition of KocherLaKota (2013) that market participants put

7 I thank Alain Gabler for pointing this possible mechanism out to me. 
more weight on macroeconomic risks during periods of exceptionally low real interest rates than in normal times.

Table 3 summarizes the results of the variance decompositions. The left panel gives the result for the baseline sample period from January 1975 to July 2013. The middle and the right panels show the corresponding results based on threshold VAR estimates for periods in which real interest rates were positive (middle panel) or negative (right panel). Below the variances and covariances, table 3 displays the $95 \%$ confidence intervals obtained from bootstrapping these statistics 1000 times. The columns "CH" and "US" report the results for Switzerland and the US respectively.

As the left panel of table 3 shows, the majority of variation in unexpected Swiss stock excess returns is related to news of future fundamentals, i.e. dividends. This finding stands in marked contrast to the US evidence which highlights that news about future excess returns and news about future cash-flows are about equally important drivers of variation in stock market returns on average over the sample period. The US evidence is broadly consistent with earlier evidence but points to a more prominent role of cash-flow news than in studies focused on the 1950s to 1980s (CAMPBELL, 1991). This increase in the importance of cash-flow news for US stock market return variation is nonetheless in line with recent evidence by Campbell, Giglio and Polk (2013) who show that cash-flow news was particularly important in the 2007-2009 US stock market bust. The Swiss evidence is consistent with Rey (2004) who examines Swiss stock returns in a similar framework (focused on stock market returns and evaluating various combinations of different state variables) and also finds that cash-flow news are the main driver of Swiss stock market returns in the sample period from 1975 to 2002. The variance decompositions in the left panel of table 3 suggest that the variation in Swiss stock excess returns would be even higher if only news of fundamentals would contribute to it. The share of the cash-flow variance normalized by the total variance is slightly higher than one. The negative co-variation of cash-flow news and news of risk premia lower the total variability of Swiss stock excess returns. De Long and Becht (1992) find similar evidence for the German stock market during the first age of globalization in the pre-World War I period. In that time period German stock returns varied slightly less than suggested by the variability of fundamentals. It should be noted, however, that cashflow news is obtained as residual in the VAR-based decomposition and therefore its importance is likely to be overstated.

The variance decompositions based on the threshold VAR estimates in the middle (positive real interest rates) and in the right (negative real interest rates) panel of table 3 show that the distinction between positive and negative real 


\section{Table 3: Stock Excess Return News: Variance Decomposition with Correlated Components}

\begin{tabular}{|c|c|c|c|c|c|c|}
\hline & \multicolumn{2}{|c|}{ Jan 1975 - July 2013} & \multicolumn{2}{|c|}{ Threshold: $r r_{t}>0$} & \multicolumn{2}{|c|}{ Threshold: $r r_{t}<0$} \\
\hline & $\mathrm{CH}$ & US & $\mathrm{CH}$ & US & $\mathrm{CH}$ & $\underline{\mathrm{US}}$ \\
\hline $\operatorname{Var}(\mathrm{NCF})$ & 1.04 & 0.23 & 1.63 & 0.46 & 1.03 & 1.14 \\
\hline$(95 \% \mathrm{CI})$ & $(0.76,1.43)$ & $(0.18,0.30)$ & $(1.27,2.08)$ & $(0.31,0.67)$ & $(0.40,2.41)$ & $(0.80,1.69)$ \\
\hline $\operatorname{Var}(\mathrm{NRR})$ & 0.01 & 0.05 & 0.01 & 0.02 & 0.01 & 0.00 \\
\hline$(95 \% \mathrm{CI})$ & $(0.01,0.01)$ & $(0.03,0.07)$ & $(0.01,0.01)$ & $(0.01,0.03)$ & $(0.00,0.01)$ & $(0.00,0.00)$ \\
\hline $\operatorname{Var}(\mathrm{NRX})$ & 0.17 & 0.20 & 0.62 & 0.39 & 0.62 & 0.09 \\
\hline$(95 \% \mathrm{CI})$ & $(0.12,0.23)$ & $(0.15,0.26)$ & $(0.44,0.84)$ & $(0.26,0.59)$ & $(0.33,1.31)$ & $(0.04,0.21)$ \\
\hline$-2 * \operatorname{Cov}(\mathrm{NCF}, \mathrm{NRR})$ & -0.02 & 0.08 & 0.13 & 0.01 & 0.02 & 0.01 \\
\hline$(95 \% \mathrm{CI})$ & $(-0.05,0.01)$ & $(0.06,0.10)$ & $(0.09,0.17)$ & $(-0.04,0.05)$ & $(-0.01,0.07)$ & $(-0.00,0.04)$ \\
\hline$-2 * \operatorname{Cov}(\mathrm{NCF}, \mathrm{NRX})$ & -0.12 & 0.37 & -1.24 & 0.01 & -0.64 & -0.24 \\
\hline$(95 \% \mathrm{CI})$ & $(-0.22,-0.03)$ & $(0.30,0.46)$ & $(-1.61,-0.91)$ & $(-0.28,0.23)$ & $(-1.35,-0.06)$ & $(-0.48,-0.07)$ \\
\hline $2^{*} \operatorname{Cov}(\mathrm{NRR}, \mathrm{NRX})$ & -0.07 & 0.07 & -0.14 & 0.11 & -0.05 & -0.02 \\
\hline$(95 \% \mathrm{CI})$ & $(-0.09,-0.06)$ & $(0.05,0.09)$ & $(-0.18,-0.10)$ & $(0.07,0.16)$ & $(-0.07,-0.02)$ & $(-0.04,-0.01)$ \\
\hline
\end{tabular}

Notes: This table gives the variance decomposition of unexpected excess returns on the Swiss and US stock market into variances and covariances of the three news components: News about cashflows, real interest rates and future excess returns. These statistics are normalized by the variance of the total stock market return news such that they sum to one. In addition, the table gives the 95\% confidence interval of the statistics after 1000 bootstrap simulations. The left panel gives the results for the baseline sample period from January 1975 to July 2013. The middle panel provides the corresponding results based on threshold VAR estimates for months in which the Swiss or US real interest rate was positive. The right panel gives the corresponding results for months in which the real interest rates were negative.

interest rates does not really matter for the Swiss stock market. Cash-flow news is always relatively more important than discount rate news.

The evidence for the US is more nuanced. While cash-flow and discount rate news are equally important in explaining variation in US stock excess returns when real interest rates are positive, it is cash-flow news that is mostly responsible for variation in stock excess returns in times of negative real interest rates in the US. This finding is very much in line with the intuition of KocHERLaKota (2013).

The evidence in favour of a pronounced role of cash-flow news in explaining variation in stock market excess returns is backed by a related strand of the literature which assesses the time variation in the dividend-price ratio. Variation in 
the dividend-price ratio has to reflect future dividend growth or expected returns or both (Cochrane, 2008). Based on US evidence it is conventional wisdom that the variation in dividend-price ratio can be almost exclusively explained by expected returns (e.g. Cochrane, 2008, 2011). However, Chen (2009) shows that dividend growth in the US was predictable by the dividend-price ratio in the pre-World War II period. VAN BINSWANGen and KoIJEn (2010) use filtering techniques to highlight that dividend growth is predictable by the dividendprice ratio in the US also in the more recent past. In addition, EnGSTED and Pedersen (2010) provide evidence for dividend growth predictability in Denmark and Sweden. Rangvid, Schmeling and Schrimpf (2013) regard a larger cross-section of countries to show that dividend-price ratios of small countries, e.g. Switzerland, do exhibit some predictive power for dividend growth as dividend smoothing is less pronounced in these countries than in the US.

\subsection{Variance Decomposition with Correlated Components: Bond Excess Return}

As for Swiss stock excess returns, news about cash-flows, here inflation news over the lifetime of the bond, dominates the variation in unexpected bond excess returns. However, the uncertainty around the share of variance explained by inflation news is quite large as reported in table 4. Again we observe the opposite pattern in US data. Here, news of future bond excess returns appear to be relatively more important in explaining bond return variation than the other news components.

These findings hold irrespective of the distinction between low or high real interest rate levels in the two countries. In all three cases cash-flow (inflation) news is the main driving force of variation in Swiss long-term bond excess returns. As discussed earlier, this finding most likely reflects the fact the Switzerland is a small, open economy for which exchange rate fluctuations have an important impact on inflation rates. Hence the evidence in favour of long-term inflation news as main driver of bond excess return variation could be largely driven by the impact of exchange rate dynamics on inflation expectations. News of future real interest rates play almost no role in this respect. The share of variation in bond excess returns explained by revisions in expectations of future bond excess returns is considerably smaller than the variance share explained by inflation news.

We observe the opposite pattern for US bond excess returns. News of future excess returns clearly dominate the variance of bond returns. The variance decompositions from standard VAR estimates and from the threshold VAR are very similar. This evidence suggests that investors in long-term US government 
bond returns were not particularly concerned about long-term inflation risks. Notice that in the bond return decomposition inflation news is directly estimated in the VAR and news of excess returns is the residual. Hence, it is rather the importance of news of bond excess returns than inflation news that is overstated in these variance decompositions.

\section{Table 4: Bond Excess Return News: Variance Decomposition with Correlated Components}

\begin{tabular}{|c|c|c|c|c|c|c|}
\hline & \multicolumn{2}{|c|}{ Jan 1975 - July 2013} & \multicolumn{2}{|c|}{ Threshold: $r r_{t}>0$} & \multicolumn{2}{|c|}{ Threshold: $r r_{t}<0$} \\
\hline & $\mathrm{CH}$ & US & $\underline{\mathrm{CH}}$ & US & $\mathrm{CH}$ & US \\
\hline $\operatorname{Var}(\mathrm{NBCF})$ & 1.21 & 0.08 & 0.78 & 0.09 & 0.94 & 0.09 \\
\hline$(95 \% \mathrm{CI})$ & $(0.69,2.12)$ & $(0.04,0.16)$ & $(0.29,1.84)$ & $(0.06,0.15)$ & $(0.46,2.12)$ & $(0.04,0.18)$ \\
\hline $\operatorname{Var}(\mathrm{NBRR})$ & 0.00 & 0.00 & 0.00 & 0.00 & 0.00 & 0.00 \\
\hline$(95 \% \mathrm{CI})$ & $(0.00,0.00)$ & $(0.00,0.00)$ & $(0.00,0.00)$ & $(0.00,0.00)$ & $(0.00,0.00)$ & $(0.00,0.00)$ \\
\hline Var(NBRX) & 0.19 & 1.07 & 0.40 & 1.03 & 0.36 & 1.12 \\
\hline$(95 \% \mathrm{CI})$ & $(0.13,0.32)$ & $(0.56,2.08)$ & $(0.24,0.70)$ & $(0.58,2.02)$ & $(0.21,0.71)$ & $(0.53,2.12)$ \\
\hline $2^{*} \operatorname{Cov}(\mathrm{NBCF}, \mathrm{NBRR})$ & -0.01 & 0.00 & -0.00 & 0.00 & -0.00 & 0.00 \\
\hline$(95 \% \mathrm{CI})$ & $(-0.01,-0.01)$ & $(0.00,0.01)$ & $(-0.01,-0.00)$ & $(0.00,0.01)$ & $(-0.00,0.00)$ & $(0.00,0.00)$ \\
\hline $2^{*} \operatorname{Cov}(\mathrm{NBCF}, \mathrm{NBRX})$ & -0.39 & -0.12 & -0.17 & -0.11 & -0.31 & -0.21 \\
\hline$(95 \% \mathrm{CI})$ & $(-0.53,-0.28)$ & $(-0.18,-0.05)$ & $(-0.35,-0.02)$ & $(-0.20,-0.03)$ & $(-0.63,-0.01)$ & $(-0.32,-0.10)$ \\
\hline $2^{*} \operatorname{Cov}(\mathrm{NBRR}, \mathrm{NBRX})$ & 0.00 & -0.03 & -0.01 & -0.01 & 0.00 & -0.00 \\
\hline$(95 \% \mathrm{CI})$ & $(0.00,0.00)$ & $(-0.05,-0.02)$ & $(-0.01,0.00)$ & $(-0.02,-0.01)$ & $(0.00,0.00)$ & $(-0.00,-0.00)$ \\
\hline
\end{tabular}

Notes: This table gives the variance decomposition of unexpected excess returns on the Swiss bond market into variances and covariances of the three components: News about cash-flows, real interest rates and future excess returns. These statistics are normalized by the variance of the total stock market return news such that they sum to one. In addition, the table gives the $95 \%$ confidence interval of the statistics after 1000 bootstrap simulations. The left panel gives the results for the baseline sample period from January 1975 to July 2013. The middle panel provides the corresponding results based on threshold VAR estimates for months in which the Swiss or US real interest rate was positive. The right panel gives the corresponding results for months in which the real interest rates were negative. 


\subsection{Correlation between Stock and Bond Excess Return News}

An interesting by-product of the return decomposition is the assessment of common movements in revisions of expectations of the different bond and stock excess return news components. In the case of Switzerland, the visual inspection of the bond and stock excess news series in figure (1) suggests that the overall covariation between stock and bond excess return news is low. However, we should expect some components to be closely linked.

\subsubsection{Swiss Evidence}

The correlation coefficients between the three respective news components of Swiss stock and bond excess returns are presented in table 5. Panel A gives the correlation coefficients for the baseline sample period from January 1975 to July 2013 and based on the news components backed out from the standard VAR. Panel B shows the corresponding statistics for the news components in times of positive real interest rates and Panel $\mathrm{C}$ the corresponding statistics for the news components in times of negative real interest rates. Bootstrapped 95\% confidence intervals of the correlation coefficients appear in parenthesis.

We see high positive correlations between the real interest rate news components irrespective of the sample period. This is a natural observation that follows from the fact the real interest rate news for stock excess returns reflects news over the infinite horizon while the real interest rate news component of the bond excess returns is measured over the life-time of the bond. Hence, these two components should be strongly positively correlated.

The variances of stock and bond excess returns, however, are dominated by their cash-flow news components. These components are only weakly correlated. In the baseline sample period, the correlation is not distinguishable from zero. In the high real interest rate periods, however, the correlation becomes positive and significant meaning that Swiss stock prices provided hedging value against long-term inflation risks in these periods. 
Table 5: Correlations of Swiss Stock and Bond Excess Return Components

\begin{tabular}{|c|c|c|c|c|c|c|}
\hline & $\begin{array}{c}\text { Stock } \\
\text { (cash-flow) }\end{array}$ & $\begin{array}{c}\text { Stock } \\
\text { (risk } \\
\text { premium) }\end{array}$ & $\begin{array}{c}\text { Stock } \\
\text { (real rate) }\end{array}$ & $\begin{array}{c}\text { Bond } \\
\text { (cash-flow) }\end{array}$ & $\begin{array}{c}\text { Bond } \\
\text { (risk } \\
\text { premium) }\end{array}$ & $\begin{array}{c}\text { Bond } \\
\text { (real rate) }\end{array}$ \\
\hline \multicolumn{7}{|c|}{ Panel A: Baseline sample period January 1975 to July 2013} \\
\hline $\begin{array}{l}\text { Stock } \\
\text { (cash-flow) }\end{array}$ & 1 & $\begin{array}{c}0.15 \\
(0.06,0.24)\end{array}$ & $\begin{array}{c}0.09 \\
(0.00,0.18)\end{array}$ & $\begin{array}{c}-0.05 \\
(-0.14,0.04)\end{array}$ & $\begin{array}{c}0.53 \\
(0.46,0.59)\end{array}$ & $\begin{array}{c}0.07 \\
(-0.02,0.16)\end{array}$ \\
\hline $\begin{array}{l}\text { Stock (risk } \\
\text { premium) }\end{array}$ & & 1 & $\begin{array}{c}-0.87 \\
(-0.89,-0.85)\end{array}$ & $\begin{array}{c}0.53 \\
(0.46,0.59)\end{array}$ & $\begin{array}{c}-0.35 \\
(-0.43,-0.27)\end{array}$ & $\begin{array}{c}-0.95 \\
(-0.96,-0.94)\end{array}$ \\
\hline $\begin{array}{l}\text { Stock } \\
\text { (real rate) }\end{array}$ & & & 1 & $\begin{array}{c}-0.54 \\
(-0.60,-0.47)\end{array}$ & $\begin{array}{c}0.26 \\
(0.17,0.34)\end{array}$ & $\begin{array}{c}0.93 \\
(0.92,0.94)\end{array}$ \\
\hline $\begin{array}{l}\text { Bond } \\
\text { (cash-flow) }\end{array}$ & & & & 1 & $\begin{array}{c}-0.41 \\
(-0.48,-0.33)\end{array}$ & $\begin{array}{c}-0.56 \\
(-0.62,-0.49)\end{array}$ \\
\hline $\begin{array}{l}\text { Bond (risk } \\
\text { premium) }\end{array}$ & & & & & 1 & $\begin{array}{c}0.31 \\
(0.23,0.39)\end{array}$ \\
\hline $\begin{array}{l}\text { Bond } \\
\text { (real rate) }\end{array}$ & & & & & & 1 \\
\hline \multicolumn{7}{|c|}{ Panel B: Threshold: $r r_{t}>0$} \\
\hline $\begin{array}{l}\text { Stock } \\
\text { (cash-flow) }\end{array}$ & 1 & $\begin{array}{c}0.62 \\
(0.55,0.68)\end{array}$ & $\begin{array}{c}-0.52 \\
(-0.60,-0.44)\end{array}$ & $\begin{array}{c}0.42 \\
(0.33,0.51)\end{array}$ & $\begin{array}{c}0.09 \\
(-0.02,0.19)\end{array}$ & $\begin{array}{c}-0.56 \\
(-0.63,-0.48)\end{array}$ \\
\hline $\begin{array}{l}\text { Stock (risk } \\
\text { premium) }\end{array}$ & & 1 & $\begin{array}{c}-0.91 \\
(-0.93,-0.89)\end{array}$ & $\begin{array}{c}0.35 \\
(0.25,0.44)\end{array}$ & $\begin{array}{c}0.72 \\
(0.66,0.76)\end{array}$ & $\begin{array}{c}-0.99 \\
(-0.99,-0.98)\end{array}$ \\
\hline $\begin{array}{l}\text { Stock } \\
\text { (real rate) }\end{array}$ & & & 1 & $\begin{array}{c}-0.32 \\
(-0.41,-0.22)\end{array}$ & $\begin{array}{c}-0.75 \\
(-0.80,-0.70)\end{array}$ & $\begin{array}{c}0.96 \\
(0.95,0.97)\end{array}$ \\
\hline $\begin{array}{l}\text { Bond } \\
\text { (cash-flow) }\end{array}$ & & & & 1 & $\begin{array}{c}-0.15 \\
(-0.26,-0.05)\end{array}$ & $\begin{array}{c}-0.34 \\
(-0.43,-0.24)\end{array}$ \\
\hline $\begin{array}{l}\text { Bond (risk } \\
\text { premium) }\end{array}$ & & & & & 1 & $\begin{array}{c}-0.77 \\
(-0.81,-0.72)\end{array}$ \\
\hline $\begin{array}{l}\text { Bond } \\
\text { (real rate) }\end{array}$ & & & & & & 1 \\
\hline
\end{tabular}


Table 5 (continued)

\begin{tabular}{|c|c|c|c|c|c|c|}
\hline & $\begin{array}{c}\text { Stock } \\
\text { (cash-flow) }\end{array}$ & $\begin{array}{c}\text { Stock } \\
\text { (risk } \\
\text { premium) }\end{array}$ & $\begin{array}{c}\text { Stock } \\
\text { (real rate) }\end{array}$ & $\begin{array}{c}\text { Bond } \\
\text { (cash-flow) }\end{array}$ & $\begin{array}{c}\text { Bond } \\
\text { (risk } \\
\text { premium) }\end{array}$ & $\begin{array}{c}\text { Bond } \\
\text { (real rate) }\end{array}$ \\
\hline \multicolumn{7}{|c|}{ Panel C: Threshold: $r r_{t}<0$} \\
\hline $\begin{array}{l}\text { Stock } \\
\text { (cash-flow) }\end{array}$ & 1 & $\begin{array}{c}0.40 \\
(0.24,0.53)\end{array}$ & $\begin{array}{c}-0.24 \\
(-0.39,-0.07)\end{array}$ & $\begin{array}{c}0.07 \\
(-0.10,0.23)\end{array}$ & $\begin{array}{c}-0.24 \\
(-0.39,-0.08)\end{array}$ & $\begin{array}{c}-0.39 \\
(-0.52,-0.23)\end{array}$ \\
\hline $\begin{array}{l}\text { Stock (risk } \\
\text { premium) }\end{array}$ & & 1 & $\begin{array}{c}-0.56 \\
(-0.66,-0.43)\end{array}$ & $\begin{array}{c}0.28 \\
(0.12,0.43)\end{array}$ & $\begin{array}{c}-0.67 \\
(-0.75,-0.56)\end{array}$ & $\begin{array}{c}-0.72 \\
(-0.79,-0.63)\end{array}$ \\
\hline $\begin{array}{l}\text { Stock } \\
\text { (real rate) }\end{array}$ & & & 1 & $\begin{array}{c}-0.16 \\
(-0.32,0.01)\end{array}$ & $\begin{array}{c}0.78 \\
(0.70,0.83)\end{array}$ & $\begin{array}{c}0.90 \\
(0.87,0.93)\end{array}$ \\
\hline $\begin{array}{l}\text { Bond } \\
\text { (cash-flow) }\end{array}$ & & & & 1 & $\begin{array}{c}-0.26 \\
(-0.41,-0.10)\end{array}$ & $\begin{array}{c}-0.09 \\
(-0.25,0.08)\end{array}$ \\
\hline $\begin{array}{l}\text { Bond (risk } \\
\text { premium) }\end{array}$ & & & & & 1 & $\begin{array}{c}0.93 \\
(0.91,0.95)\end{array}$ \\
\hline $\begin{array}{l}\text { Bond } \\
\text { (real rate) }\end{array}$ & & & & & & 1 \\
\hline
\end{tabular}

Notes: This table presents correlation coefficients between cash-flow, real interest rate and excess return news components of Swiss stock and bond excess returns obtained from a VAR with a one month lag. Below the correlation coefficients in parenthesis are the $95 \%$ confidence intervals of the statistics obtained from bootstrap simulations. Panel A gives the correlation coefficients for the sample period from January 1975 to July 2013. The middle panel provides the corresponding results based on threshold VAR estimates for months in which the Swiss real interest rate was positive. The right panel gives the corresponding results for months in which the real interest rate was negative.

\subsubsection{US Evidence}

Table 6 presents the corresponding correlation coefficients between the different news components for the US. In contrast to the Campbell and Ammer (1993) evidence from the 1950s to 1980 s, there is virtually no correlation between future stock and bond excess returns in the sample under study. This difference can be explained by the lack of predictive power of the term yield spread for excess returns in the baseline sample period as presented in table 2. Typically, the term spread predicts both stock and bond excess returns such that mechanically some positive correlation between risk premium news on the two asset markets is the result. In the setting of this paper, the US term spread exhibits no predictive power. 


\section{Table 6: Correlations of US Stock and Bond Excess Return Components}

\begin{tabular}{|c|c|c|c|c|c|c|}
\hline & $\begin{array}{c}\text { Stock } \\
\text { (cash-flow) }\end{array}$ & $\begin{array}{c}\text { Stock } \\
\text { (risk } \\
\text { premium) }\end{array}$ & $\begin{array}{c}\text { Stock } \\
\text { (real rate) }\end{array}$ & $\begin{array}{c}\text { Bond } \\
\text { (cash-flow) }\end{array}$ & $\begin{array}{c}\text { Bond } \\
\text { (risk } \\
\text { premium) }\end{array}$ & $\begin{array}{c}\text { Bond } \\
\text { (real rate) }\end{array}$ \\
\hline \multicolumn{7}{|c|}{ Panel A: Baseline sample period January 1975 to July 2013} \\
\hline $\begin{array}{l}\text { Stock } \\
\text { (cash-flow) }\end{array}$ & 1 & $\begin{array}{c}-0.88 \\
(-0.90,-0.85)\end{array}$ & $\begin{array}{c}-0.39 \\
(-0.47,-0.31)\end{array}$ & $\begin{array}{c}-0.46 \\
(-0.53,-0.38)\end{array}$ & $\begin{array}{c}0.11 \\
(0.02,0.20)\end{array}$ & $\begin{array}{c}-0.38 \\
(-0.45,-0.30)\end{array}$ \\
\hline $\begin{array}{l}\text { Stock (risk } \\
\text { premium) }\end{array}$ & & 1 & $\begin{array}{c}0.36 \\
(0.28,0.44)\end{array}$ & $\begin{array}{c}0.57 \\
(0.50,0.62)\end{array}$ & $\begin{array}{c}0.00 \\
(-0.09,0.10)\end{array}$ & $\begin{array}{c}0.33 \\
(0.25,0.41)\end{array}$ \\
\hline $\begin{array}{l}\text { Stock } \\
\text { (real rate) }\end{array}$ & & & 1 & $\begin{array}{c}0.44 \\
(0.37,0.52)\end{array}$ & $\begin{array}{c}-0.89 \\
(-0.91,-0.87)\end{array}$ & $\begin{array}{c}0.99 \\
(0.99,0.99)\end{array}$ \\
\hline $\begin{array}{l}\text { Bond } \\
\text { (cash-flow) }\end{array}$ & & & & 1 & $\begin{array}{c}-0.20 \\
(-0.29,-0.11)\end{array}$ & $\begin{array}{c}0.48 \\
(0.41,0.55)\end{array}$ \\
\hline $\begin{array}{l}\text { Bond (risk } \\
\text { premium) }\end{array}$ & & & & & 1 & $\begin{array}{c}-0.93 \\
(-0.94,-0.91)\end{array}$ \\
\hline $\begin{array}{l}\text { Bond } \\
\text { (real rate) }\end{array}$ & & & & & & 1 \\
\hline \multicolumn{7}{|c|}{ Panel B: Threshold: $r r_{t}>0$} \\
\hline $\begin{array}{l}\text { Stock } \\
\text { (cash-flow) }\end{array}$ & 1 & $\begin{array}{c}-0.01 \\
(-0.12,0.10)\end{array}$ & $\begin{array}{c}-0.04 \\
(-0.15,0.07)\end{array}$ & $\begin{array}{c}0.07 \\
(-0.04,0.18)\end{array}$ & $\begin{array}{c}0.09 \\
(-0.02,0.19)\end{array}$ & $\begin{array}{c}-0.06 \\
(-0.17,0.04)\end{array}$ \\
\hline $\begin{array}{l}\text { Stock (risk } \\
\text { premium) }\end{array}$ & & 1 & $\begin{array}{c}0.66 \\
(0.60,0.72)\end{array}$ & $\begin{array}{c}0.72 \\
(0.66,0.76)\end{array}$ & $\begin{array}{c}-0.04 \\
(-0.14,0.07)\end{array}$ & $\begin{array}{c}0.63 \\
(0.56,0.69)\end{array}$ \\
\hline $\begin{array}{l}\text { Stock } \\
\text { (real rate) }\end{array}$ & & & 1 & $\begin{array}{c}0.70 \\
(0.64,0.75)\end{array}$ & $\begin{array}{c}-0.72 \\
(-0.77,-0.67)\end{array}$ & $\begin{array}{c}0.98 \\
(0.97,0.98)\end{array}$ \\
\hline $\begin{array}{l}\text { Bond } \\
\text { (cash-flow) }\end{array}$ & & & & 1 & $\begin{array}{c}-0.19 \\
(-0.29,-0.08)\end{array}$ & $\begin{array}{c}0.75 \\
(0.70,0.79)\end{array}$ \\
\hline $\begin{array}{l}\text { Bond (risk } \\
\text { premium) }\end{array}$ & & & & & 1 & $\begin{array}{c}-0.75 \\
(-0.80,-0.70)\end{array}$ \\
\hline $\begin{array}{l}\text { Bond } \\
\text { (real rate) }\end{array}$ & & & & & & 1 \\
\hline
\end{tabular}


Table 6 (continued)

\begin{tabular}{|c|c|c|c|c|c|c|}
\hline & $\begin{array}{c}\text { Stock } \\
\text { (cash-flow) }\end{array}$ & $\begin{array}{c}\text { Stock } \\
\text { (risk } \\
\text { premium) }\end{array}$ & $\begin{array}{c}\text { Stock } \\
\text { (real rate) }\end{array}$ & $\begin{array}{c}\text { Bond } \\
\text { (cash-flow) }\end{array}$ & $\begin{array}{c}\text { Bond } \\
\text { (risk } \\
\text { premium) }\end{array}$ & $\begin{array}{c}\text { Bond } \\
\text { (real rate) }\end{array}$ \\
\hline \multicolumn{7}{|c|}{ Panel C: Threshold: $r r_{t}<0$} \\
\hline $\begin{array}{l}\text { Stock } \\
\text { (cash-flow) }\end{array}$ & 1 & $\begin{array}{c}0.36 \\
(0.20,0.51)\end{array}$ & $\begin{array}{c}-0.22 \\
(-0.38,-0.04)\end{array}$ & $\begin{array}{c}-0.33 \\
(-0.48,-0.16)\end{array}$ & $\begin{array}{c}0.19 \\
(0.01,0.36)\end{array}$ & $\begin{array}{c}-0.02 \\
(-0.19,0.16)\end{array}$ \\
\hline $\begin{array}{l}\text { Stock (risk } \\
\text { premium) }\end{array}$ & & 1 & $\begin{array}{c}-0.86 \\
(-0.90,-0.80)\end{array}$ & $\begin{array}{c}-0.16 \\
(-0.33,0.02)\end{array}$ & $\begin{array}{c}-0.32 \\
(-0.47,-0.15)\end{array}$ & $\begin{array}{c}-0.72 \\
(-0.79,-0.62)\end{array}$ \\
\hline $\begin{array}{l}\text { Stock } \\
\text { (real rate) }\end{array}$ & & & 1 & $\begin{array}{c}0.40 \\
(0.24,0.54)\end{array}$ & $\begin{array}{c}-0.08 \\
(-0.25,-0.17)\end{array}$ & $\begin{array}{c}0.90 \\
(0.86,0.93)\end{array}$ \\
\hline $\begin{array}{l}\text { Bond } \\
\text { (cash-flow) }\end{array}$ & & & & 1 & $\begin{array}{c}-0.34 \\
(-0.48,-0.17)\end{array}$ & $\begin{array}{c}0.41 \\
(0.25,0.55)\end{array}$ \\
\hline $\begin{array}{l}\text { Bond (risk } \\
\text { premium) }\end{array}$ & & & & & 1 & $\begin{array}{c}-0.20 \\
(-0.37,-0.03)\end{array}$ \\
\hline $\begin{array}{l}\text { Bond } \\
\text { (real rate) }\end{array}$ & & & & & & 1 \\
\hline
\end{tabular}

Notes: This table presents correlation coefficients between cash-flow, real interest rate and excess return news components of US stock and bond excess returns obtained from a VAR with a one month lag. Below the correlation coefficients in parenthesis are the $95 \%$ confidence intervals of the statistics obtained from bootstrap simulations. Panel A gives the correlation coefficients for the sample period from January 1975 to July 2013. The middle panel provides the corresponding results based on threshold VAR estimates for months in which the US real interest rate was positive. The right panel gives the corresponding results for months in which the real interest rate was negative.

\subsection{Summary of Robustness Checks of VAR-Based Return Decomposition}

This section summarizes robustness checks of the main results of this paper. Detailed results are available upon request. These robustness checks show that the main results are qualitatively robust to various changes in the empirical setup.

First, one might argue that financial market participants do care about oil prices. Instead of using a CPI that excludes oil related products one should take this explicitly into account when calculating the ex post real interest rate. It turns out that the qualitative results remain unaffected by the particular choice of the $\mathrm{CPI}$ to calculate inflation rates.

Second, I used growth rates of monetary aggregates as additional proxies of monetary policy in the VAR for Switzerland. It should be noted, that the shortterm market rate is already closely related to Swiss monetary policy since 2000. The SNB uses the three-month Libor as policy rate since its current policy 
framework became effective in 2000. In any case, the inclusion of monetary aggregates does not change any of the results neither for Switzerland nor for the US.

Third, I included changes in effective (nominal and real, trade-weighted) Swiss franc exchange rates as explicit state variable in the VARs to take into account that Switzerland is a small open economy such that exchange rate movements could directly influence revisions in expectations of Swiss bond and stock returns. None of the results presented in this paper is affected by the inclusion of the effective Swiss franc exchange rate changes. This does not mean, however, that they do not have an indirect effect through revisions in Swiss long-term inflation expectations as discussed earlier.

Fourth, I estimated the threshold VARs for different thresholds (also using a grid search). It turns out that the results, particularly the difference in the US stock market dynamics between high and low real interest rate periods, also hold for a range of positive real interest rate levels as threshold. The threshold of below/ above zero is not necessary to draw the main qualitative conclusions but delivers the clearest quantitative results.

Finally, I also performed the variance decompositions based on estimates from a joint seemingly unrelated regression (SUR) of the Swiss and the US system of variables instead of separate VARs for each country. This approach takes into account that the residuals obtained from the separate VARs for Switzerland and the US could be correlated. This is a valid point. As can be seen in figure 1, the residuals from the Swiss and the US stock market excess return equations in the VARs, i.e. the unexpected stock market excess returns, are significantly positively correlated over the full sample period. However, variance decompositions based on SUR estimates are qualitatively similar to the results presented in the previous subsections.

\section{Conclusions}

This paper has evaluated the relative importance of news about cash-flows, real interest rates and risk premia in explaining time variation in Swiss stock and bond excess returns. It additionally compares these results with US evidence for the same sample period. The main findings of this paper suggest that variation in Swiss asset returns mainly reflects revisions in expectations about their underlying economic fundamentals, i.e. dividends in the case of stocks and long-term inflation in the case of bonds. This observation stands in marked contrast to the evidence for the US. 
However, the relative importance of dividend news for the overall variation in US stock excess returns is stronger in periods of low real interest rates in the US. This evidence is consistent with the view that a prolonged period of low real interest rates induces agents to place more weight on expectations of macroeconomic risk, i.e. the dynamics of the economic fundamentals underlying asset prices, than in periods of "normal" real interest rate levels (Kocherlakota, 2013).

\section{References}

Campbell, John Y. (1991), "A Variance Decomposition for Stock Returns", Economic Journal, 101, pp. 157-179.

Campbell, John Y., and John Ammer (1993), "What Moves the Stock and Bond Markets? A Variance Decomposition for Long-Term Asset Returns", Journal of Finance, 48, pp.3-37.

Campbell, John Y., and John H. Cochrane (1999), "By Force of Habit: A Consumption-Based Explanation of Aggregate Stock Market Behaviour", Journal of Political Economy, 107, pp. 205-251.

Campbell, John Y., Stefano Giglio and Christopher Polk (2013), "Hard Times", Review of Asset Pricing Studies, 3, pp. 95-132.

Campbell, John Y., and Robert J. Shiller (1988), "The Dividend-Price Ratio and Expectations of Future Dividends and Discount Factors", Review of Financial Studies, 1, pp. 195-228.

Chen, Long (2009), "On the Reversal of Dividend and Return Predictability: A Tale of Two Periods", Journal of Financial Economics, 92, pp. 128-151.

Chen, Long, and Xinlei Zhao (2009), "Return Decomposition", Review of Financial Studies, 22, pp. 5213-5249.

Cochrane, John H. (2008), "The Dog That Did Not Bark: A Defense of Return Predictability”, Review of Financial Studies, 21, pp. 1533-1575.

Cochrane, John H. (2011), "Presidential Address: Discount Rates", Journal of Finance, 66, pp. 1046-1108.

De Long, J. Bradford, and Marco Becht (1992), “Excess' Volatility and the German Stock Market: 1876-1990”, NBER working paper 4054.

Engsted, Tom, Thomas Q. Pedersen and Carsten Tanggaard (2012), Pitfalls in VAR Based Return Decompositions: A Clarification", Journal of Banking and Finance, 36, pp. 1255-1265.

Engsted, Tom, and Thomas Q. Pedersen (2010), “The Dividend-Price Ratio Does Predict Dividend Growth: International Evidence", Journal of Empirical Finance, 17, pp. 585-605. 
Engsted, Tom, and Carsten Tanggaard (2001), "The Danish Stock and Bond Markets: Comovement, Return Predictability and Variance Decomposition”, Journal of Empirical Finance, 8, pp. 243-271.

Galsband, Victoria, and Thomas Nitschka (2013), "Foreign Currency Returns and Systematic Risks", forthcoming Journal of Financial and Quantitative Analysis.

Grisse, Christian, and Thomas Nitschka (2013), "On Financial Risk and the Safe Haven Characteristics of Swiss Franc Exchange Rates", SNB Working Paper 2013-04.

Habib, Maurizio M., and Livio Stracca (2012), "Getting Beyond Carry Trade. What Makes a Safe Haven Currency?”, Journal of International Economics, 87, pp. 50-64.

Hoffmann, Mathias, and Rahel Suter (2010), "The Swiss Franc Exchange Rate and Deviations From Uncovered Interest Rate Parity: Global vs Domestic Factors", Swiss Journal of Economics and Statistics, 146, pp. 349-371.

Kocherlakota, Narayana (2013), "Low Real Interest Rates", Speech given at the 22nd Annual Hyman P. Minsky Conference, Levy Economics Institute of Bard College, New York on April 18, 2013. Federal Reserve Bank of Minneapolis.

Kugler, Peter, and Beatrice Weder (2005), "Why Are Returns on Swiss Franc Assets so Low?”, Applied Economics Quarterly, 51, pp. 231-246.

Ranaldo, Angelo, and Paul Söderlind (2010), "Safe Haven Currencies", Review of Finance, 14, pp. 385-407.

Rangvid, Jesper, Maik Schmeling and Andreas Schrimpf (2013), "Dividend Predictability around the World", Forthcoming Journal of Financial and Quantitative Analysis.

Rey, David (2004), "A Variance Decomposition for Swiss Stock Market Returns", University of Basel, WWZ/Department of Finance, Working Paper No. 7/04. Shiller, Robert J., and Andrea E. Beltratti (1992), "Stock Prices and Bond Yields. Can their Comovements be Explained in Terms of Present Vale Models?", Journal of Monetary Economics, 30, pp. 25-46.

Swiss National Bank, Quarterly Bulletin 2/2013 June.

Van Binsbergen, Jules H., and Ralph S.J. Koijen (2010), "Predictive Regressions: A Present-Value Approach", Journal of Finance, 65, pp. 1439-1471.

Viceira, Luis M. (2008), "Bond Risk, Bond Return Volatility, and the Term Structure of Interest Rates", International Journal of Forecasting, 28, pp. 97-117. 


\section{SUMMARY}

Based on a vector autoregressive model (VAR), this paper shows that time variation in monthly excess returns on Swiss government bonds and stocks is predominantly driven by news of inflation and dividends, respectively. This finding is in marked contrast to US evidence which points to a more prominent role of excess return news. Variance decompositions based on estimates from threshold VARs show that US stock market evidence is consistent with the view that market participants put more weight on news of macroeconomic, i.e. cash-flow, risks in periods of exceptionally low real interest rates than in normal times. 